\title{
The Use of Portfolio in the Implementation of Problem Based Learning Model to Improve Student Learning Outcomes
}

\author{
Erma Suryani Sahabuddin \\ Universitas Negeri Makassar \\ Makassar, Indonesia \\ ermasuryani2001@yahoo.com
}

\begin{abstract}
The purpose of this study is to describe the use of portfolio in the implementation of problem-based learning to improve learning outcomes of Natural Sciences. This study is a qualitative research namely Classroom Action Research. The focus of this research is the application of problem-based learning and learning outcomes. The subjects of study were teachers and students of class $\mathrm{V}$ with the number of students 20 people, consisting of 9 boys and 11 girls. Moreover, data collecting technique used is observation, testing, and documentation. The data analysis used is qualitative and quantitative. The results showed an increase in activity and student learning outcomes. It is concluded that teaching and learning activities of teachers and students in Natural Sciences with the use of portfolio in the application of problem-based learning improve student learning outcomes.
\end{abstract}

Keywords-Portfolio; Problem Based Leaning Model; CAR; learning outcomes

\section{INTRODUCTION}

Improving the quality of human resources is the emphasis of the functions and purposes of education, as stated in the national regulation No. 20 of 2003 on National Education System Chapter II Article 3 states that: The national education serves to develop the capabilities and form the character and civilization that are useful in the context of the intellectual life of the nation, it is aimed at developing students' potentials to become a man of faith and devoted to God Almighty, noble, healthy, knowledgeable, skilled, creative, independent, and become citizens of a democratic and responsible [1], [2]. Learning conditions need to be considered to use a model that can give students the chance to reconstruct their own knowledge [3].

Based on the observations in the first semester of the academic year 2015/2016 at elementary School Karuwisi II District Panakkukang Makassar City, indicates that the results for students in natural science subjects are still low. Based on the assessment of daily tests it was found that the average of students' absorption score only 37, while the minimum completeness criteria of the students are 65 . Of these 23 students, 17 of whom failed to reach the criteria or $73.91 \%$ of the students in the classically is not reached KKM which means that only just six students in the class who reached
KKM or $26.08 \%$ of total students. In general, students who are low scores has less right conceptual in understanding the science concept itself [4].

Natural Sciences were presented in the form of the problem will provide motivation for students to learn more in the Natural Science [3]. Students when faced with a problem of Natural Sciences, will be trying to find a solution through various models of solving their problems and was accompanied by a teacher. Thus it is clear that solving the natural science problem appeared to have important position in learning natural science in elementary schools.

\section{RESEARCH METHOD}

The method chosen in the implementation of this study is a qualitative approach. This approach was chosen to describe the activities of students and teachers in conducting action learning.

This type of research is Classroom Action Research since the study was conducted by researchers with the aim of improving teacher performance therefore the learning process can run well and increasing student learning outcomes and conducted by the model [5]. According to Guskey that: Class Action Research is research that raised issues that actual undertaken by teachers which are improving learning activities in the form of action to improve and enhance classroom practice more professionally [6]. Data collection techniques used in this study are as follows Observation, Test, and Documentation [7].

The data analysis technique is a technique of qualitative and quantitative data analysis [8]. Activity in qualitative data analysis performed interactively and runs continuously until complete, so that the data is already saturated. Indicators of success in terms of the learning process, if there is an increase in learning activities both teacher and student activities obtained through observation sheet, [9].

\section{RESULTS}

Implementation of the study results consisted of findings of teachers' success in using problem-solving learning materials by using a portfolio in natural science class with 
materials about the relationship between living beings and their environment, natural resources, land, and water. The findings showed the students increase during the learning process and results. The stages in any action of learning adapted to the stages of problem-based learning model, namely: (1) student orientation to the problem; (2) Organizing students to learn; (3) To lead the investigation of individual and group with developing a Portfolio; (4) Develop and ask for work; and (5) to analyze and evaluate the problem-solving process based on the portfolio that has been compiled [10].

Description of learning for the effectiveness of the problem based learning model with using portfolios in improving student learning outcomes with the surrounding natural material served as one cycle and each cycle consisting of 2 meetings.

Exposure Data Cycle I: Implementation of the first cycle of the material relationship between living beings and the environment, natural resources, land, and water that implementation activities include planning, implementation, observation and reflection. Each activity is described as follows:

\section{A. Planning}

Planning in the first meeting is conducted by providing an early test to the students and providing the subject matter of the relationship between human and it's environment and natural resources. While the second meeting with the material of the soil, and water then the final test. The plan was conceived and developed by researchers in conjunction with the fifth grade teacher in the form of lesson plan, student worksheets, learning media and test cycles I.

Researchers also prepare observation sheets to observe the activity of teachers and students on the use of portfolio models in the application of problem-based learning at the meeting of 1 and 2. In the learning scenario, the steps in this activity includes the steps of problem-based learning model that consists of (1) student orientation to the problem; (2) organize the students to learn by the use of portfolio in the application of problem-based learning model; (3) To lead the investigation of individual and group; (4) Develop and ask for work; and (5) to analyze and evaluate the problem-solving process. Broadly speaking, learning steps performed by the teacher at the first meeting.

\section{B. Implementation}

Implementation of natural science learning by using Portfolio in the application of problem-based learning in class V SDN Karuwisi II for the first cycle held two meetings. Implementation of the learning is done by the teacher while investigators act as an observer.

Starting the action in this study, carried out by implementing measures of the problem based learning model. The first phase of student orientation to the problem, at this stage the teacher explains the material of living creatures with the help of props and followed up with a question and answer about the material that is the relation of living beings with the environment and natural resources. At the end learning activities is that making conclusions, to reflect, to motivate students to study hard at home and school and put forward the material to be taught at the next meeting and a series of learning activities ended with closing greetings from teachers. This activity takes approximately 15 minutes.

At its core activities, the learning process carried out by implementing measures of the problem-based learning model. The first phase orientation of students to the problem, at this stage the teacher explains the material on land and water with the help of props and followed up with a question and answer about the material on the environment. Moreover, teacher bring learning problems in the sample relating to the topic and invite the students to solve the problem. Teachers then organize students to learn by grouping students into four groups and each group equipment and materials to construct portfolios, which guide students to collect information by the topic of portfolio materials have been prepared. At the end learning activities that make conclusions, to reflect, to motivate students to study hard at home and school and put forward the material to be taught at the next meeting and a series of learning activities ended with closing greetings from teachers.

\section{Observation}

At the time of the learning process is ongoing, observer/researcher conducting observations of both to the students and teachers with the following results:

At each meeting the observers observe and pay attention to the teacher in the learning process by applying problem-based learning that consist of five phases: (a) student orientation to the problem; (B) Organizing students to learn; (C) To lead the investigation of individual and group; (D) Develop and ask for work; and (e) to analyze and evaluate the problem-solving process.

Based on observations of the teacher's teaching activities, data showed that at the meeting of 1 and 2 indicators to- 1 student orientation to the issues considered good for the teacher to explain the subject matter, ask questions about the material and lead to problems in learning. In indicator to-2 teachers organize students to learn, at the meeting of 1 categorized enough for teachers to group students into four groups heterogeneously but the teacher did not explain the scenario and rules to learn in small groups to solve the problem / task learning, whereas at the meeting of 2 considered good because teachers are split into 4 heterogenic groups, describing scenarios and rules to learn in small groups to solve the problem/task learning. Indicators 3rd teachers guide the investigation of individual and group, at the meeting of 1 and 2 categorized enough for the teacher to direct and guide students in doing portfolio has been prepared and encouraged students to express ideas as a form of cooperation in investigating and resolving the problem group but teachers do not guide all group.

In indicator to-5 teachers to analyze and evaluate the process of solving the problem, at the meeting of 1 and 2 are categorized less because teachers only advice to the reports that have been reported by any group but does not encourage students to actively discuss and give responses to grain results 
of problem-solving and did not examine or discuss the proposed opinion.

Teacher's teaching activity observation sheet used to determine the activity of students in learning science by applying measures of problem-based learning model with the use of the portfolio. At each meeting the observers observe and pay attention to the teacher in the learning process by applying problem-solving learning consists of five phases: (a) student orientation to the problem; (B) Organizing students to learn; (C) To lead the investigation of individual and group; (D) Develop and ask for work; and (e) to analyze and evaluate the problem-solving process.

In all indicators and ask the teacher to develop the work. Based on data from the first cycle can be concluded that the achievement of the implementation of activities to learn science through the application of problem-based learning model by using a portfolio for students categorized aspect enough.

\section{Learning Results}

After the implementation of the first cycle of the learning process that consists of two sessions, then at the first meeting, preliminary tests are conducted. The descriptive analysis results from the score acquisition of the students' early test score after the implementation of problem-based learning model can be seen in the table below:

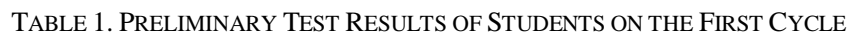

\begin{tabular}{|c|c|}
\hline Illustration & Score \\
\hline Subject & 20 \\
\hline Ideal Score & 100 \\
\hline Avarage & 61 \\
\hline Highest Score & 70 \\
\hline Lowest Score & 30 \\
\hline
\end{tabular}

The Table 1 shows that 20 students who obtain an average score of the class is 61 , the highest score is 70 , and the lowest score is 30 , with the ideal score of 100 .

Description of Percentage distribution for frequency and thoroughness of learning natural science learning outcomes after the application of problem-based learning model in the first cycle can be seen in the table below:

TABLE 2. DISTRIBUTION OF FREQUENCY AND PERCENTAGE OF COMPLETENESS PRELIMINARY TESTS FIFTH GRADE SCIENCE STUDENTS AT SDN KARUWISI II DISTRICT PANAKKUKANG MAKASSAR CITY.

\begin{tabular}{|c|c|c|c|}
\hline Score Range & Category & Frequency & Percentage (\%) \\
\hline $0-64$ & Not Finish & 8 & $40 \%$ \\
\hline $65-100$ & Finish & 12 & $60 \%$ \\
\hline \multicolumn{2}{|c|}{ Total } & 20 & $100 \%$ \\
\hline
\end{tabular}

The table 2 shows that eight students (40\%) do not complete the initial test and 12 students $(60 \%)$ have completed initial tests on learning natural science. It means that in the first cycle in the classical mastery learning outcomes in science teaching has not been achieved because of the number of students who study results completed less than $85 \%$ of $60 \%$ means that there are $40 \%$ of students are expected to complete their study results.

After the implementation of the first cycle of the learning process that consists of two sessions, then the second meeting conducted final tests. The results of the descriptive analysis of the score acquisition score early test students after the implementation of problem-based learning model can be seen in the table below:

TABLE 3. Final Test Results

\begin{tabular}{|c|c|}
\hline Illustration & Scores \\
\hline Subject & 20 \\
\hline Ideal Score & 100 \\
\hline Average & 88 \\
\hline Highest Score & 100 \\
\hline Lowest Score & 60 \\
\hline
\end{tabular}

The Table 3 indicates that the description of the final test through problem-based learning model with the subject 20 students, obtaining an average score of a class of 88 , the highest score of 100 the lowest score of 60 , with the ideal score of 100 .

Percentage distribution description of frequency and thoroughness for learning science learning outcomes after application of problem-based learning model in the first cycle 2nd meeting can be seen in the table below:

TABLE 4. DISTRIBUTION OF FREQUENCY AND PERCENTAGE OF COMPLETENESS FINAL TESTS

\begin{tabular}{|c|c|c|c|}
\hline Score Range & Category & Frequency & $\begin{array}{c}\text { Percentage } \\
(\mathbf{\%})\end{array}$ \\
\hline $0-64$ & Not Complete & 2 & $10 \%$ \\
\hline $65-100$ & Complete & 18 & $90 \%$ \\
\hline \multicolumn{2}{|c|}{ Total } & 20 & $100 \%$ \\
\hline
\end{tabular}

The Table 4 indicates where 20 students of class V SDN Karuwisi II Panakkukang District Makassar City there are two students $(10 \%)$ who did not complete the test ended and 18 students $(90 \%)$ who have completed tests ended in learning science. This means that in the first cycle in the classical mastery learning outcomes in science teaching has been reached because the number of students who study results completed more than $85 \%$ of $90 \%$.

\section{E. Reflection}

In the first cycle of implementation, learning focused on improving learning outcomes by implementing the use of IPA Portfolio in the application of problem-based learning to obtain data on the implementation of the action first cycle of observation and tests [11].

\section{DISCUSSION}

Student learning outcomes obtained after execution the first cycle in science learning with the principal relationships between living things and the environment, natural resources, land, and water by applying problem-based learning model, 
the average score obtained at the meeting of 1 is 61 with a value centipede 70 and the lowest 30 from the ideal score of 100 , and the complete study results and the 12 students who did not complete study results from 8 students. This is due to lack of motivation to learn, lack of knowledge of students in completing the portfolio so that students are not interested in science subjects are given even if teachers give instructions in a group [12], but the task is still dominated by students who are active (smart) only. Other students who just watch and told me, they would not cooperate. Therefore, after the study is completed, more teachers to provide direction and guidance on how to complete the story about Natural Science.

In the first cycle, meeting 2, learning implementation is not much different from the first meeting. Every meeting is successful because teachers can implement the lesson plan well by the steps of the Use of Portfolio in the application of problem-based learning model. Thereby increasing student learning outcomes SDN Karuwisi class V District Panakkukang Makassar City for their good cooperation in the group and the guidance and direction of the teacher. Facts that prove that the application of problem-based learning model can improve learning outcomes, especially in the use of science Portfolio.

\section{CONCLUSION}

Based on the above results it can be concluded that: with the teaching activities in science class learning with the use of portfolio in the application of problem-based learning increased significantly. With the average value of science learning outcomes in the first cycle in the category of less (not yet completed), then the second cycle of the average value of student learning outcomes that are in the very good category (complete) was measured using shaped test description.

\section{References}

[1] J. W. Rigney, 'Learning strategies: A theoretical perspective', Learn. Strateg., vol. 165, 1978.

[2] C. Day, Developing teachers: The challenges of lifelong learning. Psychology Press, 1999.

[3] G. Anderson and G. J. Anderson, Fundamentals of educational research. Psychology Press, 1998.

[4] J. A. Van de Walle, Elementary School Mathematics, Teaching Developmentally. ERIC, 1990.

[5] C. A. Mertler, Action research: Teachers as researchers in the classroom. Sage, 2008.

[6] T. R. Guskey, 'Professional development in education: in search of the optimal mix.', 1994.

[7] S. Hadi, Effective teacher professional development for the implementation of realistic mathematics education in Indonesia. University of Twente, 2002.

[8] D. R. Krathwohl, Methods of educational and social science research: An integrated approach. Longman/Addison Wesley Longman, 1993.

[9] D. Hart, Authentic Assessment: A Handbook for Educators. Assessment Bookshelf Series. ERIC, 1994.

[10] R. Farr and B. Tone, Portfolio and performance assessment: Helping students evaluate their progress as readers and writers. ERIC, 1998.

[11] K. Kraiger, J. K. Ford, and E. Salas, 'Application of cognitive, skillbased, and affective theories of learning outcomes to new methods of training evaluation.', J. Appl. Psychol., vol. 78, no. 2, p. 311, 1993.

[12] D. W. Johnson, Cooperative learning in the classroom. ERIC, 1994. 